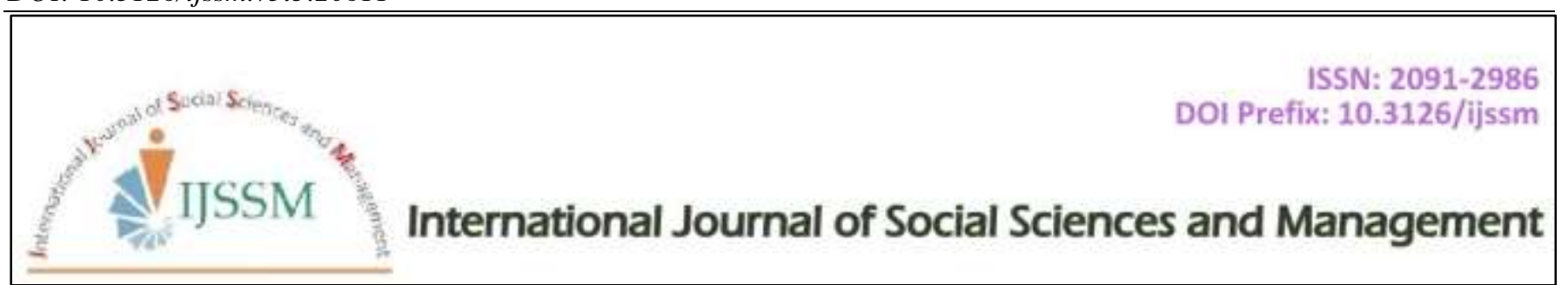

Research Article

\title{
Relationship between Leadership Styles of Nurse Managers and Staff Nurses Job Satisfaction in Public Hospital of Punjab, Pakistan
}

\author{
Sofia Naseem ${ }^{1 *}$, Muhammad Afzal ${ }^{1}$, Sana Sehar ${ }^{1}$, Syed Amir Gilani ${ }^{1}$ \\ ${ }^{1}$ Lahore school of Nursing, The University of Lahore, Pakistan
}

\begin{abstract}
Introduction: Nurses are the "backbone" of any human services framework and their work is varied and extremely complicated. When carrying out their jobs, nurses faces different circumstances and patients, which are elements of the circumstances and patient level workloads. In addition, higher amount of nurse's dissatisfaction prompts to leave out from the nursing profession. This generally creates staff shortage among nurses. Due to enhances extra time and job stress, increases burnout, longer patient holding up records, lastly, as an outcome expanded displeasure among patients Leadership is the way toward impacting representatives to accomplish organizational goals and objectives Methods: This analytical, cross-case study was conducted in public hospital of Lahore. Respondents 'selection was convenient sampling technique. Selected sample was 211 registered nurses. Well adopted questionnaire as per Likert scale was used in this study. Results: The finding of this study showed that caregivers prefer transformational styles of leaders to achieve optimal presentation of nurses. The results showed that there is statistically significance as p-value $<0.05$ at all level of job satisfaction. Conclusions: A transformative leadership style promotes job satisfaction among nurses, which improves performance. Nurses job performance increased proportionally by increasing job satisfaction. In the current health system, it is necessary to develop leadership behaviors that have proven to be effective in the implementation of positive and adaptive behaviors among nurses.
\end{abstract}

Keywords: Leadershuip style; Job satisfaction; Registred nurses

\section{Introduction}

Nurses are the "backbone" of any human services framework and their work is varied and extremely complicated. When carrying out their jobs, nurses faces different circumstances and patients, which are elements of the circumstances and patient level workloads (Mudihanselage and Chamaru, 2015).Employees' job satisfaction, which is depicted as "the degree to which workers like their occupations" has been an essential issue for medicinal services associations and their pioneers. Leadership is the way toward impacting representatives to accomplish organizational goals and objectives (Konstantinou and Prezerakos, 2017).In addition, higher amount of nurse's dissatisfaction prompts to leave out from the nursing profession. This generally creates staff shortage among nurses. Due to enhances extra time and job stress, increases burnout, longer patient holding up records, lastly, as an outcome expanded displeasure among patients (Masum et al., 2016).

In Pakistan, work overload is causing dissatisfaction among nurses resulting in poor quality of patient care and poor performing health system. In addition, professional, financial insufficiencies as well as attitude of colleagues and managers leadership styles are the major factors leading to dissatisfaction of nursing work force. By

\section{Cite this article as:}

S. Naseem et al. (2018) Int. J. Soc. Sc. Manage. Vol. 5, Issue-3: 201-208. DOI: 10.3126/ijssm.v5i3.20611

$1 *$ Corresponding author

Sofia Naseem,

Lahore school of Nursing, The University of Lahore, Pakistan

Email: Sofich965@gmail.com

Peer reviewed under authority of IJSSM

(C) 2018 International Journal of Social Sciences and Management

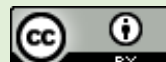

This is an open access article \& it is licensed under a Creative Commons Attribution 4.0 International License (https://creativecommons.org/licenses/by/4.0/) 
addressing these issues, satisfaction of nursing staff can be improved and will attract more competent people in this profession (Waqar and Hamid, 2016).In the human services division, the job satisfaction of experts plays a viable and solid part in their execution and is additionally reflected in the wellbeing and satisfaction of the patients (Ali and Wajidi, 2013). Moreover, here is a direct connection among leadership style of nurse manger on registered nurses job satisfaction. Managers must examine and get authority practices that are viewed as participatory. Whereby staff feel engaged and joined into the fundamental basic leadership process (Perez, 2014). However, one of the most imperative variable effects on job satisfaction is the leadership style of employee's manager. Employees' relationship with their manager is a fundamental determinant of job satisfaction (Despres, 2011).

Moreover, several styles of leadership, in that nurse managers have portrayed guide the health care provider in clinical settings. A lot of nurses' managers was supposed transactional and transformational leadership style as the best style in health care setting and in administrations (Negussie and Demissie, 2013). Transformational pioneers rouse their supporters to share a dream, utilize objectives as inspirational motivation. Supporters are invigorated to think old issues in new ways and are viewed as autonomously. Besides, supporters are affected by a transformational pioneer who is straightforward, respectable and committed (Lin, MacLennan, Hunt, and Cox, 2015).Transactional leadership offers subordinates clearness around tenets, norms to secure the position quo and involves carefully observing and improving followers' mistake to warrant short term achievement. Transactional leadership impulses supporters to perform and understand their work regarding vital means focusing on rules, duties, desires, strength, keeping away from blunders, and existing, temporary plan (Hamstra, Van Yperen, Wisse, and Sassenberg, 2011).

\section{Aims of the study}

The aim of this study was to examine the impact of leadership styles of nurse managers on job satisfaction of registered nurses in Punjab, Pakistan.

\section{Research Question}

What is the relationship between leadership styles of nurse manager and job satisfaction levels of registered staff nurses in Punjab Pakistan?

\section{Research Hypothesis}

HO: Leadership styles may not have relationship with job satisfaction among registered nurses.

H1: Leadership styles may have relationship with job satisfaction among registered nurses.

\section{Significance of the Study}

Nurses are working in the front line of a health care organization and provide direct nursing care to patients. Manager's leadership styles have great impact on nurse's performance. The result of this study data will help the nurse manager to adopt best possible leadership style which leads staff nurses towards greater satisfaction levels. Improved satisfaction level of nurses will also help in greater retention of nurses, lower turnover ratio and improved manager-nurse relationship. Moreover, this study findings will help health care provider particularly nurse manager to find which leadership style is best, either transformational or transactional. With best leadership style they feel satisfied with their job, think emphatically and show positivism in their clinic and in hospital setting in this way, they will begin to feel better about their profession.

\section{Conceptual framework}

Conceptual framework is given in Fig.1

\section{Literature Review}

Transformational leadership style gives the vision, mission and awareness of the industry or any organization which makes the high level of ability and capability. As per Bass (1985), the transformational leadership style is an organized way by which subordinate or colleagues praise and appreciate their leaders (Fasola et al., 2013).There are four essential elements of transformational leadership as assigned by Bernard Bass. The result of leadership is improved profitability and expanded job satisfaction with organization. Transformational pioneers show practices that can be classified into four distinct sub styles (Ramey, 2002).

A study conducted by Johns in 2014 revealed the leadership styles effects on nurses' level of job satisfaction. He established a transformational leadership style improved level of nurses' job satisfaction (Jones, 2014).

Moreover, a study conducted in Malaysia by Voon and his colleagues in (2011) exposed that each of the four magnitudes of transformational leadership were observed to be completely connected with working situation. The study gave confirmation to help the utilization of transformational leadership to enhance job satisfaction. Worker satisfaction with their task additionally related to inspirational motivation $(\mathrm{p}<.0 .05)$ intellectual stimulation $(\mathrm{p}<.0 .05)$ individual consideration $(\mathrm{p}<.0 .05)$ and idealized influence ( $\mathrm{p}<.0 .05$ )(Voon, Lo, Ngui, and Ayob, 2011). Moreover, a study conducted by Ohunakin et al ( 2016 ) in South west Nigeria showed relationship between the contingent reward

and job satisfaction .Outcome of this show a positive connection between contingent reward and job satisfaction. The relationship is significant at 0.05 or $5 \%$ level of significance and $\mathrm{P}$ value is $(<0.005)$. Transactional leadership style is task oriented. It gives reward based on performances and has positive relationship with followers and job satisfaction(Ohunakin et al., 2016). 


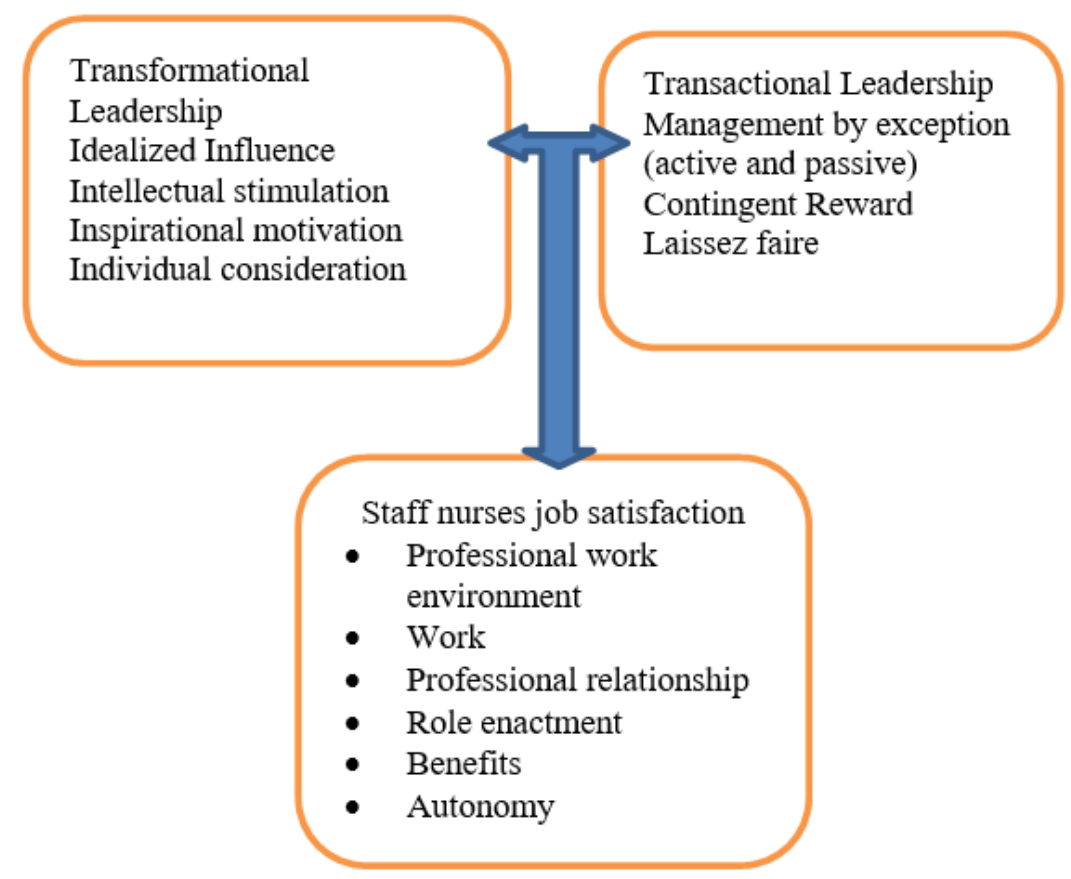

Fig.1: Conceptual framework

\section{Methods}

\section{Setting}

The research was conducted in Public hospital of Lahore, Pakistan.

\section{Research Design}

Quantitative analytical cross sectional study.

\section{Population}

The target populations were registered nurses.

\section{Sampling}

Respondents' selection was convenient sampling technique. Selected sample was 211 which was calculated according to Slovin's formula.

\section{Research Instrument}

Study tool comprises on independent variable and dependent variable. A well adopted questionnaire used for this study (Ramey, 2002). Leadership style of nurse manager consists of 45 questions using a 5 point Likert rating scale 1-5. Job satisfaction consists of 38 questions using a 7 point Likert scale.

\section{Data Gathering Procedure}

Convenient sampling technique was used for data collection.

\section{Methods Used to Analyze Data}

Data was reported using descriptive and inferential statistics.

Descriptive: After collection the data, the data was analyzed on SPSS version 21. Mean, median, and mode were computed for data.
Inferential statistics: Analysis was performed through ANOVA to analyze the relationship among demographics with job satisfaction. Relationship between leadership style and job satisfaction was analyzed by regression.

\section{Ethical Consideration}

Written permission was taken from the Ethical committee of LSN department in University of Lahore. Permission was taken from the Deputy Nursing Superintendent of Punjab Institute of Cardiology Lahore to conduct research study. Subjects were free to participate. All the participants were informed about the purpose of the study.

\section{Results}

This section presents the outcomes of the study.

\section{Profile of the Respondents}

Respondents were taken from government Hospital. Table 1 shows the demographic response of study participants in which $100 \%$ of participants responded. There were all the female nurses $n=211$ who were working in that area. To analyze the number of participants according to their age, the mean age of participants were 29.81. To analyze the number of participants according to their marital status, it was noted that $109(51.7 \%)$ out of 211 charge nurses were married as compared with unmarried was 102(48.3\%). Qualifications of nurses $\mathrm{n}=154(73 \%)$ were diploma holder, $\mathrm{n}=50(23.07 \%)$ were specialization, $\mathrm{n}=7(3.3 \%)$ were Post RN /BScN.

For the working experience it was noted that 116(55\%) out of 211 charge nurses were having working experience in range of 6-10 years, whereas, 57(27.0\%) nurses were in 05 years working experience, rest of staff nurses having experience $26(12.3 \%)$ and $12(5.7 \%)$ of $11-15$ and $16-20$ years respectively. Total $\mathrm{N}=211$. 
To determine the data is normally distributed or not, used test of Normality. The data showed that all Leadership Styles' and job satisfaction variables are normally distributed (Table 2).
To determine whether any of the differences between the means are statistically significant, compare the p-value to significance level. It is observed that age of participants, professional qualification and job experience of participants and Job satisfaction are statistically significant with level of job satisfaction as p-value $<0.05$ (Table 3 ).

Table 1: Demographic Response of Study Participants

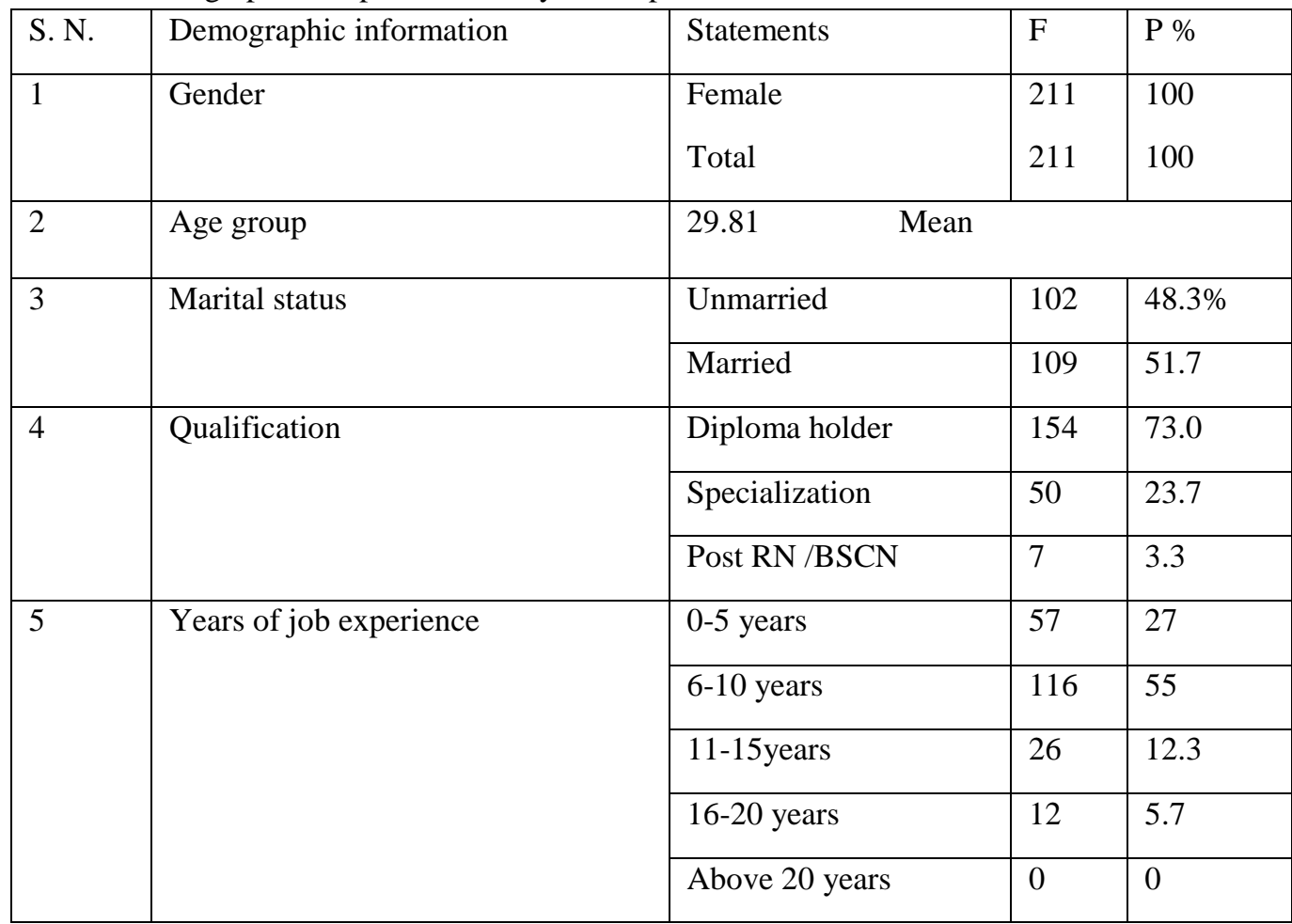

Table 2: Shapiro-Wilk Normality for Variables

\begin{tabular}{|c|c|c|c|c|}
\hline & Statistic & $\mathrm{df}$ & Sig. & \\
\hline Transformational Leadership (Idealized Influence Behavior) & 0.025 & 211 & 0.087 & \\
\hline Transformational Leadership (Idealized Influence Attributed) & 0.150 & 211 & 0.256 & \\
\hline Transformational Leadership (Inspirational Motivation) & 0.122 & 211 & 0.568 & \\
\hline Transformational Leadership (Intellectual Stimulation) & 0.136 & 211 & 0.987 & \\
\hline Transactional leadership (Contingent Reward) & 0.296 & 211 & 0.689 & \\
\hline Transformational Leadership (Individual Consideration) & 0.152 & 211 & 0.759 & \\
\hline Transactional Leadership management by-Exception(Active) & 0.259 & 211 & 0.756 & Normally \\
\hline Transactional Leadership management by-Exception(Passive) & 0.098 & 211 & 0.893 & Distributed \\
\hline Transactional Leadership Laissez-fair & 0.235 & 211 & 0.951 & \\
\hline Leader's Outcomes & 0.357 & 211 & 0.853 & \\
\hline Professional Work Environment & .0 .295 & 211 & 0.987 & \\
\hline Autonomy of practice & 0.234 & 211 & 0.972 & \\
\hline Work Worth to self and others & 0.123 & 211 & 0.678 & \\
\hline Professional Relationship & 0.598 & 211 & 0.657 & \\
\hline Professional Role Enactment & 0.456 & 211 & 0.891 & \\
\hline Benefits & 0.719 & 211 & 0.753 & \\
\hline
\end{tabular}


Table 3: One-Way ANOVA of demographic characteristics and job satisfaction

\begin{tabular}{|c|c|c|c|c|c|c|c|}
\hline \multirow{2}{*}{\multicolumn{2}{|c|}{ Demographic Factors }} & \multicolumn{6}{|c|}{ JOB satisfaction factors } \\
\hline & & \multirow{2}{*}{$\begin{array}{l}\text { Professional } \\
\text { Work } \\
\text { Environment } \\
0.994\end{array}$} & \multirow{2}{*}{$\begin{array}{l}\text { Autonomy } \\
\text { of practice }\end{array}$} & \multirow{2}{*}{$\begin{array}{l}\text { Work } \\
\text { Worth to } \\
\text { self and } \\
\text { others } \\
2.946\end{array}$} & \multirow{2}{*}{$\begin{array}{l}\text { Professional } \\
\text { Relationship } \\
4.367\end{array}$} & \multirow{2}{*}{$\begin{array}{l}\text { Professional } \\
\text { Role } \\
\text { Enactment } \\
3.624\end{array}$} & \multirow{2}{*}{$\begin{array}{l}\text { Benefits } \\
\\
5.923\end{array}$} \\
\hline Gender of & ANOVA & & & & & & \\
\hline päticesant & Sig. (2-tailed) & 0.267 & 0.487 & 0.345 & 0.378 & 0.256 & 0.689 \\
\hline \multirow{2}{*}{$\begin{array}{l}\text { Age of } \\
\text { participants. }\end{array}$} & ANOVA & 0.893 & 1.152 & 1.046 & 1.553 & 0.927 & 0.693 \\
\hline & Sig. (2-tailed) & 0.044 & 0.029 & 0.040 & 0.043 & 0.053 & 0.034 \\
\hline \multirow{2}{*}{$\begin{array}{l}\text { Marital status } \\
\text { of participants }\end{array}$} & ANOVA & 0.785 & 1.276 & 1.533 & 1.079 & 0.704 & 0.811 \\
\hline & Sig. (2-tailed) & 0.796 & 0.192 & 0.087 & 0.367 & 0.838 & 0.747 \\
\hline \multirow{2}{*}{$\begin{array}{l}\text { Qualification } \\
\text { of participants }\end{array}$} & ANOVA & 0.707 & 0.814 & 1.116 & 0.992 & 1.893 & 0.932 \\
\hline & Sig. (2-tailed) & 0.034 & 0.026 & 0.031 & 0.048 & 0.011 & 0.013 \\
\hline \multirow{2}{*}{$\begin{array}{l}\text { Job experience } \\
\text { of participants }\end{array}$} & ANOVA & 1.314 & 1.254 & 0.855 & 1.307 & 1.182 & 0.889 \\
\hline & Sig. (2-tailed) & 0.013 & 0.020 & 0.028 & 0.014 & 0.025 & 0.037 \\
\hline
\end{tabular}

\begin{tabular}{|c|c|c|c|c|c|c|c|}
\hline \multirow{2}{*}{\multicolumn{2}{|c|}{ Transformational Leadership }} & \multicolumn{6}{|c|}{ Job Satisfaction } \\
\hline & & $\begin{array}{l}\text { Professional } \\
\text { Work } \\
\text { Environment }\end{array}$ & $\begin{array}{l}\text { Autonomy } \\
\text { of practice }\end{array}$ & $\begin{array}{l}\text { Work } \\
\text { Worth } \\
\text { to self } \\
\text { and } \\
\text { others }\end{array}$ & $\begin{array}{l}\text { Professional } \\
\text { Relationship }\end{array}$ & $\begin{array}{l}\text { Professional } \\
\text { Role } \\
\text { Enactment }\end{array}$ & Benefits \\
\hline \multirow[t]{2}{*}{$\begin{array}{l}\text { Idealized Influence } \\
\text { Behavior }\end{array}$} & $\begin{array}{l}\text { Correlation } \\
\text { Coefficient }\end{array}$ & $.175^{*}$ & $.307^{* *}$ & $.143^{*}$ & $.347^{* *}$ & $.286^{* *}$ & $.174^{*}$ \\
\hline & $\begin{array}{l}\text { Sig. (2- } \\
\text { tailed) }\end{array}$ & 0.011 & 0.000 & 0.037 & 0.000 & 0.000 & 0.011 \\
\hline \multirow[t]{2}{*}{ Attributed } & $\begin{array}{l}\text { Correlation } \\
\text { Coefficient }\end{array}$ & $.236^{* *}$ & $.270^{* *}$ & $.325^{* *}$ & $.383^{* *}$ & $.235^{* *}$ & $.291^{* *}$ \\
\hline & $\begin{array}{l}\text { Sig. (2- } \\
\text { tailed) }\end{array}$ & 0.001 & 0.000 & 0.000 & 0.000 & 0.001 & 0.000 \\
\hline \multirow[t]{2}{*}{$\begin{array}{l}\text { Inspirational } \\
\text { Motivation }\end{array}$} & $\begin{array}{l}\text { Correlation } \\
\text { Coefficient }\end{array}$ & $.313^{* *}$ & $.274^{* *}$ & $.236^{* *}$ & $.200^{* *}$ & $.294^{* *}$ & $.254^{* *}$ \\
\hline & $\begin{array}{l}\text { Sig. (2- } \\
\text { tailed) }\end{array}$ & 0.000 & 0.000 & 0.001 & 0.004 & 0.000 & 0.000 \\
\hline \multirow[t]{2}{*}{ Stimulation } & $\begin{array}{l}\text { Correlation } \\
\text { Coefficient }\end{array}$ & .126 & $.278^{* *}$ & $.239^{* *}$ & $.391^{* *}$ & $.193^{* *}$ & $.180^{* *}$ \\
\hline & $\begin{array}{l}\text { Sig. }(2- \\
\text { tailed) }\end{array}$ & 0.067 & 0.000 & 0.000 & 0.000 & 0.005 & 0.009 \\
\hline \multirow[t]{2}{*}{$\begin{array}{l}\text { Individual } \\
\text { Consideration }\end{array}$} & $\begin{array}{l}\text { Correlation } \\
\text { Coefficient }\end{array}$ & $.279^{* *}$ & $.235^{* *}$ & $.273^{* *}$ & $.290^{* *}$ & $.187^{* *}$ & $.277^{* *}$ \\
\hline & $\begin{array}{l}\text { Sig. (2- } \\
\text { tailed) }\end{array}$ & 0.000 & 0.001 & 0.000 & 0.000 & 0.006 & 0.000 \\
\hline Contingent Reward & $\begin{array}{l}\text { Correlation } \\
\text { Coefficient }\end{array}$ & $.318^{* *}$ & $.303^{* *}$ & $.349^{* *}$ & $.299^{* *}$ & $.276^{* *}$ & $.267^{* *}$ \\
\hline
\end{tabular}




\begin{tabular}{|c|c|c|c|c|c|c|c|}
\hline \multicolumn{2}{|c|}{ Table 4: Correlation between Leade } & \multicolumn{6}{|c|}{ Job Satisfaction } \\
\hline \multicolumn{2}{|c|}{ Transformational Leadership } & Professional & Autonomy & Work & Professional & Professional & Benefits \\
\hline \multirow{3}{*}{ Exception(Active) } & $\begin{array}{l}\text { Sig. }(2- \\
\text { tailed })\end{array}$ & 0.000 & 0.000 & 0.000 & 0.000 & 0.000 & 0.000 \\
\hline & $\begin{array}{l}\text { Correlation } \\
\text { Coefficient }\end{array}$ & $.162^{*}$ & $.251^{* *}$ & $.186^{* *}$ & $.336^{* *}$ & $.138^{*}$ & $.348^{* *}$ \\
\hline & $\begin{array}{l}\text { Sig. }(2- \\
\text { tailed) }\end{array}$ & 0.018 & 0.000 & 0.007 & 0.000 & 0.045 & 0.000 \\
\hline \multirow[t]{2}{*}{ Exception(Passive) } & $\begin{array}{l}\text { Correlation } \\
\text { Coefficient }\end{array}$ & .088 & .074 & $.157^{*}$ & .095 & $.149^{*}$ & $.143^{*}$ \\
\hline & $\begin{array}{l}\text { Sig. }(2- \\
\text { tailed) }\end{array}$ & 0.201 & 0.282 & 0.022 & 0.167 & 0.031 & 0.039 \\
\hline \multirow[t]{2}{*}{ Laissez-fair } & $\begin{array}{l}\text { Correlation } \\
\text { Coefficient }\end{array}$ & .024 & -.037 & .026 & .006 & .059 & .008 \\
\hline & $\begin{array}{l}\text { Sig. }(2- \\
\text { tailed })\end{array}$ & 0.728 & 0.591 & 0.705 & 0.935 & 0.396 & 0.908 \\
\hline \multirow[t]{2}{*}{ Leader's Outcomes } & $\begin{array}{l}\text { Correlation } \\
\text { Coefficient }\end{array}$ & $.178^{* *}$ & $.174^{*}$ & $.220^{* *}$ & $.365^{* *}$ & $.161^{*}$ & $.379^{* *}$ \\
\hline & $\begin{array}{l}\text { Sig. }(2- \\
\text { tailed) }\end{array}$ & 0.010 & 0.011 & 0.001 & 0.000 & 0.019 & 0.000 \\
\hline
\end{tabular}

Table 5: Regression Analysis of Leadership Style and Staff Nurses Job satisfaction

\begin{tabular}{lllllll}
\hline \multicolumn{7}{c}{ Coefficients } \\
\hline \multicolumn{1}{l}{ Model } & Unstandardized Coefficients & Standardized Coefficients & T & Sig. \\
& B & Std. Error & Beta & & \\
1 & (Constant) & 102.231 & 5.952 & & 17.176 & .000 \\
& Leadership Style & .277 & .032 & .509 & 8.550 & .000 \\
\hline
\end{tabular}

a. Dependent Variable: All Total

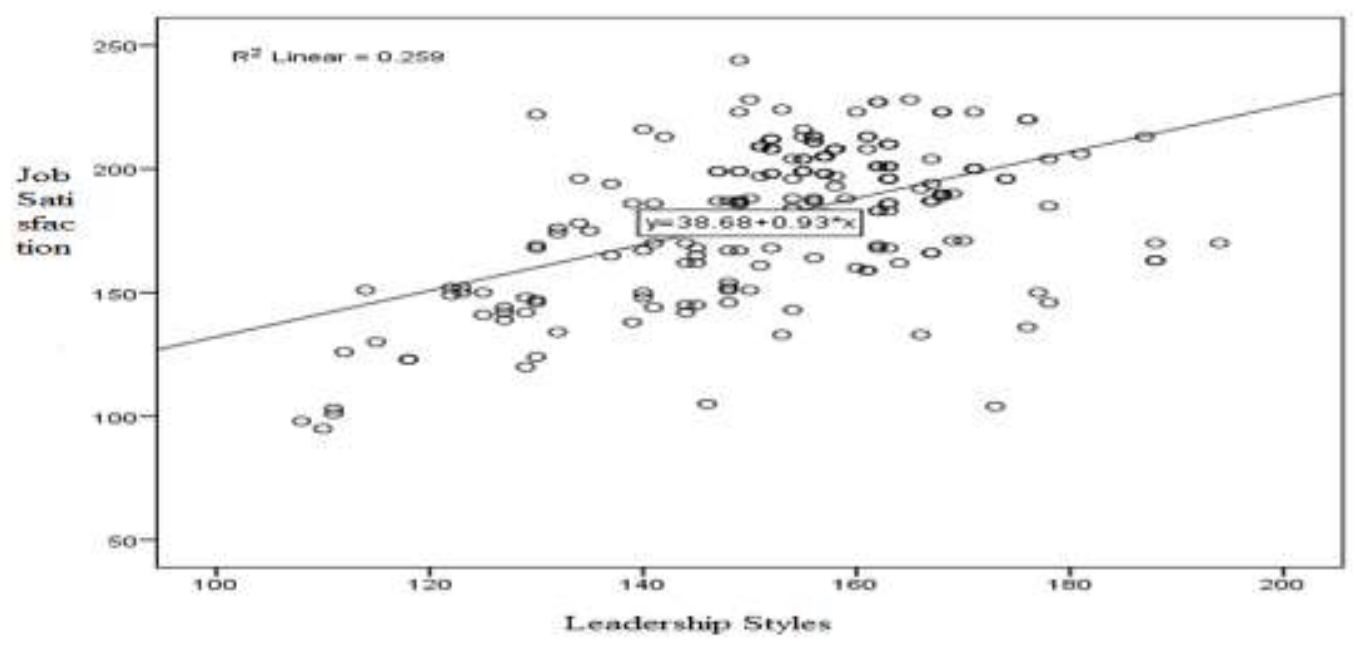

Fig. 2: Correlation between leadership styles of head nurses and registered nurses job satisfaction

Table 4 shows correlation between leadership styles of head nurses and registered nurses job satisfaction. The results reveal most factors of leadership styles of head nurse significantly correlate with job satisfaction. While there is 
no statistically significance between stimulation and professional working environment, Exception (Passive) and Laissez-fair with all factors of job satisfaction (Fig. 2).

Table 5. Showed that $\mathrm{P}$-value is significant and standardized coefficient beta 0.509 that's mean all variables of professional Leadership styles effect at $50.9 \%$.

\section{Discussion}

The purpose of this study was to examine the influence of leadership style of nurse managers on registered nurses level of job satisfaction. The current study showed the mean age of participants was 28.81 years old, it was observed that the participants of the study was female.

Overall results are supported by the findings of Karadag (2015). As indicated by them transformational authority sows a positive outcome at job fulfillment levels amongst the registered nurses. In addition, this outcome is bolstered by (Laschinger, Finegan, and Wilk, 2009) who exhibited that there is an impact of leadership styles on each nurse and her level of job satisfaction. There is a direct and a positive connection between work fulfillment level and transformational authority. These elements play an immediate impact on the result of a patient (Casida and Parker, 2011; Mah'd Alloubani et al. 2014).

Our study indicates that Inspirational motivation is when there is a pioneer who creates and advances a dream and team spirit amongst the representatives. This is additionally strengthened by the Multifactor Leadership Model as indicated by which supporters are more motivated toward pioneers who demonstrate enthusiasm and hopefulness (KALAW, 2014). Besides, as indicated by Ahmad, A. R et.al (2013) job satisfaction can be built through a style of initiative which shows inspiration and motivation. An inspirational pioneer is devoted to drive supporters to take good qualities as their obligations toward the organization.

Job satisfaction is not easy as head nurses have to regain their social network within the work context and revise the way they have learned how to proceed and work. Moreover, in order to fully adapt to the new position, they need to cope with the new compensation, relationships and work environment. Demographic characteristics have effect of different factors of job satisfaction. It was observed that only age, professional qualification and working experience have contribution for job satisfaction as p-value $<0.05$. A study conducted by Echevarria, Patterson, and Krouse (2017) they found that the bachelor degree nurses satisfaction is higher and it is produced by a conflict for associate degree nurses.

Regression analysis results exposed that all dimensions of leadership styles had a relationship on job satisfaction. Previous research has shown that laissez-fair leadership models are the least effective forms of leadership and can negatively affect job satisfaction (Yahaya and Ebrahim, 2016). The reason why Laissez-faire pioneers do not struggled to make contracts with workers, to inspire them, to set norms or to give advice (Smith, Eldridge, and DeJoy, 2016).

In contract, in this study all magnitudes of the transformative leadership style correlated significantly and positively with job satisfaction, results reveal that most factors of leadership styles of head nurse significantly correlate with job satisfaction while there is no statistically significance between variable stimulation with professional working environment, Exception(Passive) and Laissez-fair with all factors of job satisfaction like Professional Work Environment, Autonomy of practice, Work Worth to self and others, Professional Relationship, Professional Role Enactment and Benefits due to working environment, stimulation, laissez-fair leadership style can trigger among nurses for high level of job satisfaction.

Negussie, N., and Demissie, A (2013) conducted a study, they found that in general, nurses were more satisfied with transformational leadership style. Therefore, nursing managers must adopt a transformative leadership style to increase nursing job satisfaction. Results showed that a statistically significant positive relationship between transformational leadership and job satisfaction

\section{Strength of the Study}

$>$ No previous study was conducted on the relationship between leadership style of nurse managers on registered nurses job satisfaction in Pakistan, which is the strength of this study.

$>$ This study was conducted on large sample size. So the result of this study can be generalized.

$>$ Study design is cross sectional, as cross-sectional studies relatively faster and is inexpensive particularly when compared with cohort studies (prospective).

\section{Limitations}

$>$ In this study convenient sampling technique was used which is a limitation of this study. Because data is collected from easily available participants and biasness may occur.

$>$ This study is bounded to only one hospital

\section{Conclusion}

The purpose of this study was to examine the impact of leadership style of nurse managers on registered nurses job satisfaction. The finding of this study showed that nurses prefer managers who are transformation leaders. This implies that a transformative leadership style promotes job satisfaction among nurses, which improves performance. Nurses job performance increased proportionally by 
increasing job satisfaction. In the current health system, it is necessary to develop leadership behaviors that have proven to be effective in the implementation of positive and adaptive behaviors among nurses. It is important that nurse managers receive the opportunity and are trained to further improve their management skills.

\section{Acknowledgement}

Thanks to all study participants. I am much thankful to my supervisor Ms Sana, principal of LSN Mr M Afzal and authority of university of Lahore for all co-operations to extend this study. I am thankful to my friend Amna Habib for helping me during research. Also, thanks to all peers who kindly supported encouraged or facilitated me during my study process.

\section{References}

Ahmad AR, Adi MNM, Noor HM, Rahman AGA and Yushuang $T$ (2013) The influence of leadership style on job satisfaction among nurses. Asian Social Science 9(9): 172.

Ali RM and Wajidi FA (2013) Factors influencing job satisfaction in Public Healthcare Sector of Pakistan. Global Journal of Management And Business Research.

Casida J and Parker J (2011) Staff nurse perceptions of nurse manager leadership styles and outcomes. Journal of Nursing Management 19(4): 478-486.

Despres KK (2011) Perceived leadership styles of nurse managers' and nurses' job satisfaction: A correlational study. University of Phoenix.

Echevarria IM, Patterson BJ and Krouse A (2017) Predictors of transformational leadership of nurse managers. Journal of Nursing Management 25(3): 167-175.

Fasola O, Adeyemi M and Olowe F (2013) Exploring the relationship between transformational, transactional leadership style and organizational commitment among Nigerian banks employees. International Journal of Academic Research in Economics and Management Sciences 2(6): 96.

Hamstra MR, Van Yperen NW, Wisse B and Sassenberg K (2014) Transformational and transactional leadership and followers' achievement goals. Journal of Business and Psychology, 29(3): 413-425.

Jones WL (2014) Leadership Styles and Nursing Satisfaction Rates. Walden University.

Kalaw JF (2014) Organizational Culture among Teaching Employees of Lyceum of the Philippines UniversityBatangas: Basis of Enhancement. Business and Management, 6(4).

Karadağ E (2015) Leadership and organizational outcomes: Meta-analysis of empirical studies: Springer
Konstantinou C and Prezerakos P (2017) Relationship Between Nurse Managers' Leadership Styles and Staff Nurses' Job Satisfaction in a Greek NHS Hospital. American Journal of Nursing Science 7(3): 45.

Laschinger HKS, Finegan J and Wilk P (2009) Context matters: The impact of unit leadership and empowerment on nurses' organizational commitment. Journal of nursing administration 39(5): 228-235.

Lin PY, MacLennan S, Hunt N and Cox T (2015) The influences of nursing transformational leadership style on the quality of nurses' working lives in Taiwan: a cross-sectional quantitative study. BMC nursing 14(1): 33.

Mah'd Alloubani A, Almatari M and Almukhtar MM (2014) Effects of Leadership Styles on quality of services in healthcare. European Scientific Journal, ESJ: 10(18).

Masum AKM, Azad MAK, Hoque KE, Beh LS, Wanke P and Arslan Ö (2016) Job satisfaction and intention to quit: an empirical analysis of nurses in Turkey. PeerJ, 4: e1896.

Mudihanselage HSSS and Chamaru AAA (2015) The nursing shortage impact on job outcome (the case in Sri Lanka). Journal of Competitiveness, 7(3).

Negussie N and Demissie A (2013) Relationship between leadership styles of Nurese managers and nurses' job satisfaction in Jimma University Specialized Hospital. Ethiopian journal of health sciences, 23(1): 50-58.

Ohunakin F, Adeniji A and Akintayo ID (2016) Transactional Leadership Style and Employee Job Satisfaction among Universities' Guest Houses in South-West Nigeria.

Perez JWL (2014) Impact of nurse managers' leadership styles on staff nurses' intent to turnover: Gardner-Webb University.

Ramey JW (2002) The relationship between leadership styles of nurse managers and staff nurse job satisfaction in hospital settings.

Smith TD, Eldridge F and DeJoy DM (2016) Safety-specific transformational and passive leadership influences on firefighter safety climate perceptions and safety behavior outcomes. Safety science, 86: 92-97.

Voon ML, Lo MC, Ngui KS and Ayob NB (2011) The influence of leadership styles on employees' job satisfaction in public sector organizations in Malaysia. International Journal of Business, Management and Social Sciences, 2(1): 24-32.

Waqar S and Hamid S (2016) Job satisfaction among nurses in public and private hospitals of rawalpindi and islamabad. Pakistan Journal of Public Health, 6(4): 44-48.

Yahaya R and Ebrahim F (2016) Leadership styles and organizational commitment: literature review. Journal of Management Development, 35(2): 190-216. 